\author{
ETH Zürich \\ Institut für Nutztierwissenschaften \\ Physiologie und Verhalten \\ Vorsteher: Prof. Dr. Wolfgang Langhans \\ Institut für Veterinärphysiologie \\ der Vetsuisse-Fakultät Universität Zürich \\ Prof. Dr. Thomas Lutz
}

Arbeit unter Leitung von Dr. Jacquelien Hillebrand

\title{
Hepatic-Portal Vein Infusions of Glucagon-Like Peptide-1 Reduce Meal Size and Increase c-Fos Expression in the Nucleus Tractus Solitarii, Area Postrema and Central Nucleus of the Amygdala in Rats
}

\author{
Inaugural-Dissertation \\ zur Erlangung der Doktorwürde der \\ Vetsuisse-Fakultät Universität Zürich \\ vorgelegt von \\ Isabelle Baumgartner \\ Tierärztin \\ von Sirnach TG \\ genehmigt auf Antrag von \\ Prof. Dr. Wolfgang Langhans, Referent \\ Prof. Dr. Thomas Lutz, Korreferent
}




\section{Inhaltsverzeichnis}

Seite

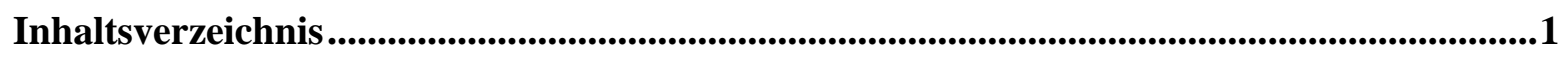

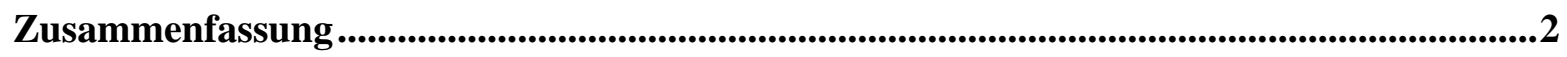

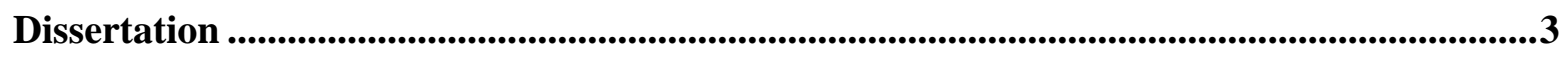

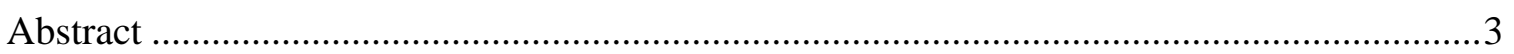

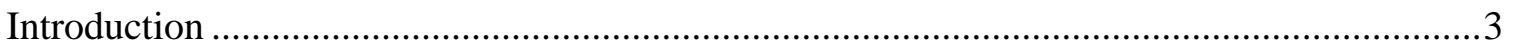

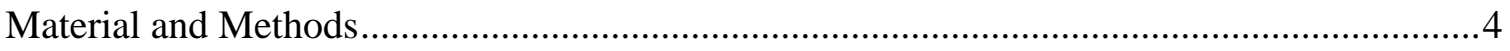

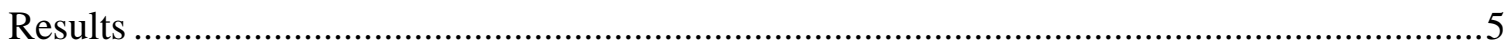

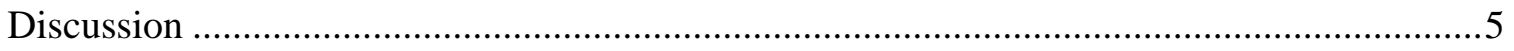

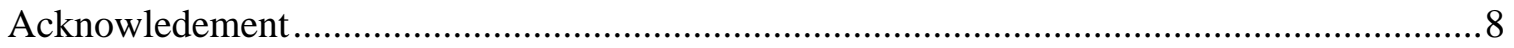

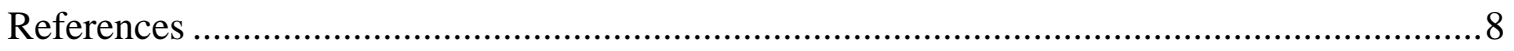

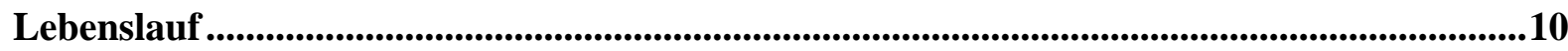




\section{Zusammenfassung}

Die Infusion von Glucagon-Like Peptide-1 in die Pfortader reduziert die Mahlzeitgrösse und erhöht die Expression von c-Fos im Nucleus tractus solitarii, in der Area postrema und im Zentralkern der Amygdala bei Ratten

Kürzlich berichteten wir, dass kurze, ferngesteuerte Infusionen von Glucagon-Like Peptide-1 (GLP-1) in die Pfortader von Ratten während einer Mahlzeit die spontane Mahlzeitengrösse reduzieren. Um die verhaltensneurologischen Wechselwirkungen dieses Effekts zu untersuchen, implantierten wir männlichen Sprague-Dawley Ratten Pfortaderkatheter und erfassten den Einfluss von ferngesteuerten Infusionen von GLP-1 (1 nmol/kg, $5 \mathrm{~min}$ ) oder Kontrolllösung auf den Verzehr während der ersten Mahlzeit in der Dunkelphase nach 3h Futterentzug. Ferner erfassten wir den Einfluss analoger GLP-1 Infusionen am Beginn der Dunkelphase auf die c-Fos Expression in mehreren Gehirnarealen, welche in die Steuerung des Verzehrs involviert sind. GLP-1 reduzierte $(\mathrm{P}<0.05)$ die Grösse der ersten Mahlzeit in der Dunkelphase und steigerte deren Sättigungsquotienten (Dauer des nachfolgenden Mahlzeitenintervals [min]/Mahlzeitgrösse [g]). Ebenso vermehrte $(\mathrm{P}<0.05)$ GLP-1 die Anzahl der c-Fos exprimierenden Zellen im Nucleus tractus solitarii, in der Area postrema und im Zentralkern der Amygdala, nicht aber im Nucleaus arcuatus oder im Nucleus paraventricularis des Hypothalamus. Diese Daten lassen darauf schliessen, dass der Nucleus tractus solitarii, die Area postrema und der Zentralkern der Amygdala für den verzehrshemmenden Effekt von GLP-1 nach Infusion in die Pfortader eine Rolle spielen. Es bleibt festzustellen, ob die Aktivierung dieser Hirnareale Sättigung, Aversion oder beides reflektiert.

Schlüsselwörter: Verzehr, Sättigung, intestinales Peptid, Hinterhirn, Aversion 


\section{Hepatic-Portal Vein Infusions of Glucagon-Like Peptide-1 Reduce Meal Size and Increase c-Fos Expression in the Nucleus Tractus Solitarii, Area Postrema and Central Nucleus of the Amygdala in Rats}

I. Baumgartner, G. Pacheco-López, E. B. Rüttimann, M. Arnold, L. Asarian, W. Langhans, N. Geary and J. J. G. Hillebrand

Physiology and Behaviour Laboratory, Institute of Food, Nutrition and Health, ETH Zurich, Schwerzenbach, Switzerland.

\section{Journal of Neuroendocrinology}

Correspondence to:

Jacquelien J. G. Hillebrand, PhD, ZGT Clinical Chemistry, Geerdinksweg 141, 7555 DL, Hengelo, The Netherlands (e-mail: j.hillebrand@zgt.nl).
We recently reported that brief, remotely controlled intrameal hepatic-portal vein infusions of glucagon-like peptide-1 (GLP-1) reduced spontaneous meal size in rats. To investigate the neurobehavioural correlates of this effect, we equipped male Sprague-Dawley rats with hepaticportal vein catheters and assessed (i) the effect on eating of remotely triggered infusions of GLP-1 (1 nmol/kg, $5 \mathrm{~min})$ or vehicle during the first nocturnal meal after $3 \mathrm{~h}$ of food deprivation and (ii) the effect of identical infusions performed at dark onset on c-Fos expression in several brain areas involved in the control of eating. GLP-1 reduced $(P<0.05)$ the size of the first nocturnal meal and increased its satiety ratio. Also, GLP-1 increased $(P<0.05)$ the number of c-Fos-expressing cells in the nucleus tractus solitarii, the area postrema and the central nucleus of the amygdala, but not in the arcuate or paraventricular hypothalamic nuclei. These data suggest that the nucleus tractus solitarii, the area postrema and the central nucleus of the amygdala play a role in the eating-inhibitory actions of GLP-1 infused into the hepatic-portal vein; it remains to be established whether activation of these brain nuclei reflect satiation, aversion, or both.

Key words: eating, satiation, gut peptide, hindbrain, aversion.

doi: 10.1111/j.1365-2826.2010.01995.x
Glucagon-like peptide-1-(7-36)-amide (GLP-1) is synthesised and released by L-cells in the distal ileum and colon and by a small population of neurones in the nucleus tractus solitarii (NTS) $(1,2)$. GLP-1 receptors (GLP-1R) are widely expressed both in the brain and in the periphery, where they are found in the gastrointestinal tract, pancreatic islets, portal vein, liver and vagus nerve $(1,2)$. GLP-1 is considered to have a range of physiological actions, including stimulation of insulin secretion (i.e. an incretin effect) $(1,2)$, inhibition of glucagon secretion $(1,3)$, inhibition of gastrointestinal secretory and motor functions (i.e. ileal brake effect) (4), control of autonomic and behavioural stress and aversion responses $(5,6)$ and inhibition of eating $(1,6-8)$.

The effects of GLP-1 on eating include specific reductions in meal size ('satiation') $(5,8-11)$ and nonspecific anorexia (e.g. the anorexia produced by the visceral malaise that both directly inhibits eating and leads to the formation of conditioned taste aversions) $(5,10,12-15)$. The conditions under which (endogenous) GLP-1 produces satiation or malaise-related anorexia, and the relative contributions of peripheral and central GLP-1 and GLP-1R to these actions, remain unclear. Perhaps the strongest evidence that peripheral GLP-1 can have a specific satiating effect comes from the observations that i.p. administration of the GLP-1 antagonist exendin (9-39) acutely increased eating in rats under some conditions (11) and that i.v. infusion of physiological doses of GLP-1 (i.e. doses that mimic the increase in endogenous GLP-1 following meals) were sufficient to decrease food intake in humans without side effects $(7,16)$.

Recent findings from our laboratory indicate that peripheral GLP-1 acts at two different sites to inhibit eating in rats (9). In tests of brief, remotely controlled, infusions of $10 \mathrm{nmol} / \mathrm{kg}(33 \mu \mathrm{g} / \mathrm{kg}) \mathrm{GLP}-1$ during spontaneous meals, the eating-inhibitory effect of i.p. infused GLP-1 depended on intact abdominal vagal afferents, whereas the effect of hepatic-portal vein (HPV) infusions of GLP-1 did not. These data demonstrate that vagal afferent signalling is not necessary for the eating-inhibitory effect of HPV GLP-1 and are consistent with the idea that i.p. GLP-1, perhaps similar to endogenous GLP-1, inhibits eating by activating GLP-1R on vagal afferents terminating in the lamina propria of the intestinal mucosa. We also 
observed that HPV GLP-1 infusions failed to inhibit eating more potently than vena caval infusions of the same GLP-1 dose, indicating that the GLP-1R mediating the eating-inhibitory effect of HPV GLP-1 are not located in the HPV area or in the liver. A recent study finding that GLP-1 inhibited eating more after intrajugular than after HPV infusion also supports this interpretation (17). Taken together, these data suggest that circulating GLP-1 may act on GLP-1R in the brain to inhibit eating.

Brain areas involved in processing of satiation signals are commonly investigated using c-Fos immunohistochemistry (IHC). As reviewed below, there are few studies associating the effects of GLP-1 on eating and c-Fos expression. In particular, the effects of i.v. administration of GLP-1 on c-Fos expression in the brain have not been characterised. Therefore, in the present study we aimed to determine the effects of HPV infusion of $1 \mathrm{nmol} / \mathrm{kg} \mathrm{GLP}-1$, a moderate dose that reliably reduced spontaneous meal size under our conditions (9), on neural activation, as measured by c-Fos IHC, in several brain areas involved in the control of eating.

\section{Materials and methods}

\section{Subjects and housing}

Male Sprague-Dawley [Crl:CD $\left.{ }^{\circledR}(S D)\right]$ rats (Charles River, Sulzfeld, Germany), weighing 180-200 g body weight upon arrival, were individually housed in acrylic infusion cages $[21 \times 37 \times 41 \mathrm{~cm}$, length $(I) \times$ width $(w) \times$ height $(h)]$ with stainless steel grid floors under a $12: 12 \mathrm{~h}$ dark/light cycle (lights off $12.00 \mathrm{~h})$ in a climate-controlled room $\left(22 \pm 2{ }^{\circ} \mathrm{C}\right.$ and $60 \%$ relative humidity). Ground chow (3433; Provimi Kliba SA, Kaiseraugst, Switzerland) was available in food cups that were accessible in a niche $[5 \times 7 \times 30 \mathrm{~cm}$ $(I \times w \times h)], 6 \mathrm{~cm}$ above the cage floor, on one side of the cage. Tap water was available ad lib. A 60-W red incandescent light bulb provided dim illumination during the dark phase, and a radio tuned to a music station was played continuously to mask extraneous noise. All protocols were approved by the Veterinary Office of the Canton of Zurich.

\section{Catheter implantation and patency checks}

Two weeks after arrival, chronic HPV infusion catheters were implanted in all rats, as described previously (9). Catheters were flushed with $0.2 \mathrm{ml}$ of $0.9 \%$ sterile saline and filled with $80 \mu \mathrm{l}$ of heparinised saline (100 IU hepa$\mathrm{rin} / \mathrm{ml}$ saline; Heparin; Braun, Melsungen, Germany) daily the first week after surgery and every 3 days thereafter. Catheter patency was verified by infusing $0.8 \mathrm{ml} / \mathrm{kg}$ body weight of a mixture of $26 \mathrm{mg} / \mathrm{kg}$ ketamine (Ketasol-100; Dr E. Gräub AG, Bern, Switzerland) and $0.9 \mathrm{mg} / \mathrm{kg}$ xylazine (Rompun; Bayer, Leverkusen, Germany) at the end of behavioural tests. The criterion for catheter patency was a complete loss of muscle tone within 1 min. In addition, in Experiment 2, $0.5 \mathrm{ml}$ of Giemsa stain (SigmaAldrich, Buchs, Switzerland) was infused into the HPV after laparotomy, and the perfusion of the HPV with blue stain without leakage was verified. In Experiment 2, the criteria for catheter patency were that both the anesthesia test and the Giemsa stain tests be successful. Data from rats without patent HPV catheters were not included in the analyses.

\section{Experiment 1: eating}

Tests began 2 weeks after surgery. Food cups were mounted on electronic balances (XS4001S; Mettler-Toledo, Greifensee, Switzerland) linked to a computer that sampled the weight of each balance every $30 \mathrm{~s}$. Meal patterns were analysed with custom-made software (LabX-Meal-analyzer 1.4; Mettler-Toledo). In addition, rats were monitored with infrared video cameras (Conrad Electronic GmbH, Hirschau, Germany). A meal was defined as a decrease of $>0.3 \mathrm{~g}$ in food cup weight and visual verification of eating. Experimenters in an adjacent control room monitored the balance weights and rats' behaviour and triggered the infusions by remote control. Twelve rats (body weight $=346 \pm 4 \mathrm{~g}$ ) were adapted to the following procedure for several days: (i) $08.15 \mathrm{~h}$, weigh rats; (ii) $09.00 \mathrm{~h}$, remove food; (iii) $11.00 h$, attach HPV catheters to the infusion pumps as described previously (9); (iv) $12.00 \mathrm{~h}$, offer fresh ground chow; (v) 2 min after the onset of the first meal, start HPV infusion ( $0.2 \mathrm{ml} / \mathrm{min}$ for $5 \mathrm{~min}$ ) of $1 \mathrm{nmol} / \mathrm{kg} \mathrm{GLP-1(7-}$ 36)-amide (Bachem, Bubendorf, Switzerland) dissolved in phosphate-buffered saline (PBS) with 1\% bovine serum albumin (Sigma-Aldrich) or vehicle; and (vi) $16.00 \mathrm{~h}$, disconnect rats from infusion pumps and flush catheters. GLP-1 and vehicle were tested on consecutive days using a within-subjects crossover design.

\section{Experiment 2: c-Fos immunohistochemistry}

Sixteen rats underwent similar surgical procedures as for Experiment 1. Two weeks after surgery, rats were adapted to the infusion protocol and to a 19-h feeding - 5-h (09.00-14.00 h) food deprivation schedule. The experiment was performed after a few weeks of adaptation, when rats weighed $442 \pm 11 \mathrm{~g}$. GLP-1 $(1 \mathrm{nmol} / \mathrm{kg}$ body weight, $n=9)$ or vehicle $(n=7)$ was infused $(0.2 \mathrm{ml} / \mathrm{min}, 5 \mathrm{~min})$ at the onset of dark $(12.00 \mathrm{~h}$, food was not returned) and, 90 min later, rats were deeply anesthetised with an i.p. injection of $100 \mathrm{mg} / \mathrm{kg}$ body weight sodium pentobarbital (Cantonal Pharmacy, Zurich, Switzerland) and transcardially perfused with PBS (0.1 M, pH 7.2) followed by $4 \%$ paraformaldehyde (Electron Microscopy Sciences, Hatfield, PA, USA). Infusions and perfusions were performed at 5-min intervals within $25 \mathrm{~min}$ of the times given above. Brains were excised and post-fixed overnight at $4{ }^{\circ} \mathrm{C}$, then switched to $30 \%$ sucrose in $0.1 \mathrm{~m} \mathrm{PBS}$, and kept at $4{ }^{\circ} \mathrm{C}$ until processing.

Brains were sectioned using a freezing sliding microtome (Microm International, Walldorf, Germany) and 40- $\mu \mathrm{m}$ sections were collected and stored in $0.1 \mathrm{~m}$ PBS with $0.1 \%$ sodium azide (Fluka, Buchs, Switzerland) at $4{ }^{\circ} \mathrm{C}$. Every sixth section of the forebrain (i.e. each $240 \mu \mathrm{m}$ ) and every twelfth section of the hindbrain (i.e. each $480 \mu \mathrm{m}$ ) were processed for c-Fos using a standard single-label indirect IHC technique (18). Briefly, after endogenous peroxidase quenching $\left(0.5 \% \mathrm{H}_{2} \mathrm{O}_{2}, 0.1 \mathrm{~m} \mathrm{PBS}, 30 \mathrm{~min}\right.$, at room temperature; RT), and blocking nonspecific interactions and permeabilisation (5\% normal goat serum, $0.1 \mathrm{~m}$ PBS, 0.3\% Triton-X, $1 \mathrm{~h}, \mathrm{RT}$ ), brain sections were incubated with primary antibody $(1: 2500$ rabbit antic-Fos; 72 h, $4^{\circ} \mathrm{C}$, sc-52; Santa Cruz Biotech., Santa Cruz, CA, USA). Afterwards, sections were incubated with a secondary biotinylated antibody (1:200 goat anti-rabbit IgG; 2 h, RT; Vector Laboratories, Burlingame, CA, USA). The antibody complex was visualised by allowing the streptavidindiaminobenzidine (DAB)-peroxidase ( $A B C$ kit; Vector Laboratories) to react with the DAB-tetrahydrochloride substrate (5 min, RT; Sigma-Aldrich). All incubation steps were performed on an orbital shaker at approximately $250 \mathrm{~Hz}$, and several interim rinse steps were performed throughout the procedure. Sections were then mounted on gelatin-coated slides, dehydrated in an increasing series of alcohols, defatted in xylene, and coverslipped with Permount (Menzel, Braunschweig, Germany). Photomicrographs were digitally acquired under $\times 20$ magnification and bright-field illumination using an Olympus AX-70 microscope (Olympus, Center Valley, PA, USA) connected to a digital colour camera interfaced to a computer. Photomicrographs were assigned to the nearest anterior-posterior bregma level according to a rat brain atlas (19), and c-Fos-positive cells were counted within the regions of interest (ROI). Transparencies made from the brain atlas were used to delineate ROI at the closest anterior-posterior level, and cell counting was performed using VoLocity 4 software 
(Improvision, Coventry, UK; settings: 65-85\% of intensity, $30 \mu \mathrm{m}^{2}$ < object size $>200 \mu \mathrm{m}^{2}$ ), operated by an experimenter who was blind to the treatments. Brain structures counted were: NTS (six sections between 13.08 and $15.48 \mathrm{~mm}$ posterior to bregma), area postrema (AP; one section at approximately $14.04 \mathrm{~mm}$ posterior), central nucleus of the amygdala (CeA; eight sections between 1.56 and $3.24 \mathrm{~mm}$ posterior), arcuate nucleus (nine sections between 1.72 and $3.64 \mathrm{~mm}$ posterior), and hypothalamic paraventricular nucleus (PVN; eight sections between 0.72 and $2.04 \mathrm{~mm}$ posterior).

\section{Statistical analysis}

Meal sizes (first and second) during the test period, intermeal interval (IMI) (duration between the end of the first meal and the start of the second meal), and first meal satiety ratio (IMI/first meal size) were analysed with paired-sample t-tests using SPSS, version 16.0 (SPSS Inc., Chicago, IL, USA). c-Fos-positive cell counts in the anterior-posterior regions of the NTS, CeA, arcuate nucleus and PVN in which c-Fos-positive cells were detected were analysed by two-way ANOVA with treatment (GLP-1, vehicle) and bregma level as factors. Significant ANOVA interaction effects were followed-up with Bonferroni-Holm contrasts (20) between GLP-1- and vehicle-treated rats at each bregma level. Because only one section in the AP was counted, c-Fos-positive cells in this area were analysed using an independent-sample t-test. To increase statistical power, data were converted to standard scores using the median absolute deviate method (21). Extreme values, defined as standard scores with absolute values $>1.96$ (i.e. $P<0.05$ ), were excluded. The incidence of such values was: NTS, 5\%; AP, 13\%; CeA, 23\%; arcuate nucleus, 17\%; and PVN 10\%. A nonparametric reanalysis of the complete data sets yielded the same effects as the post-hoc parametric analysis. Data are presented as the mean \pm SEM, and the standard error of the difference (SED) is given as a measure of residual error variability. $P<0.05$ was considered statistically significant.

\section{Results}

\section{Experiment 1: eating}

HPV infusions of $1 \mathrm{nmol} / \mathrm{kg} \mathrm{GLP}-1$ reduced the size of the first meal ( $t_{8}=2.82, P=0.02, S E D=0.6 \mathrm{~g}$ ) (Fig. $1 \mathrm{~A}$ ) and increased the first meal satiety ratio $\left(t_{8}=4.16, P=0.003, S E D=3.8 \mathrm{~min} / \mathrm{g}\right)$ versus vehicle treatment (Fig. 1B). The IMI between the first and second meals $\left(t_{7}=0.34, P>0.05, S E D=17 \mathrm{~min}\right.$ ) and the size of the second meal $\left(t_{7}=1.39, P>0.05, S E D=0.6 \mathrm{~g}\right)$ were not significantly affected by GLP-1 (Fig. 1C,D). The analyses were performed on ten rats that passed the catheter patency test.

\section{Experiment 2: c-Fos immunohistochemistry}

HPV GLP-1 infusion increased the number of c-Fos-positive cells in the NTS between 13.08 and $14.52 \mathrm{~mm}$ posterior to bregma (interaction effect: $F_{3,36}=4.06, \quad P<0.001, \quad S E D=10$ cells $/$ section), although post-hoc tests detected a significant difference between GLP-1- and vehicle-treated rats only at $14.04 \mathrm{~mm}$ posterior to bregma (Fig. 2A). HPV GLP-1 infusion significantly increased the number of c-Fos-positive cells in the AP at this level as well (Fig. $2 \mathrm{~B} ; \mathrm{t}_{11}=-2.63, \mathrm{P}=0.02, \mathrm{SED}=28$ cells/section). Representative examples of $c$-Fos staining in the NTS and AP are given in Fig. 2(C,D).
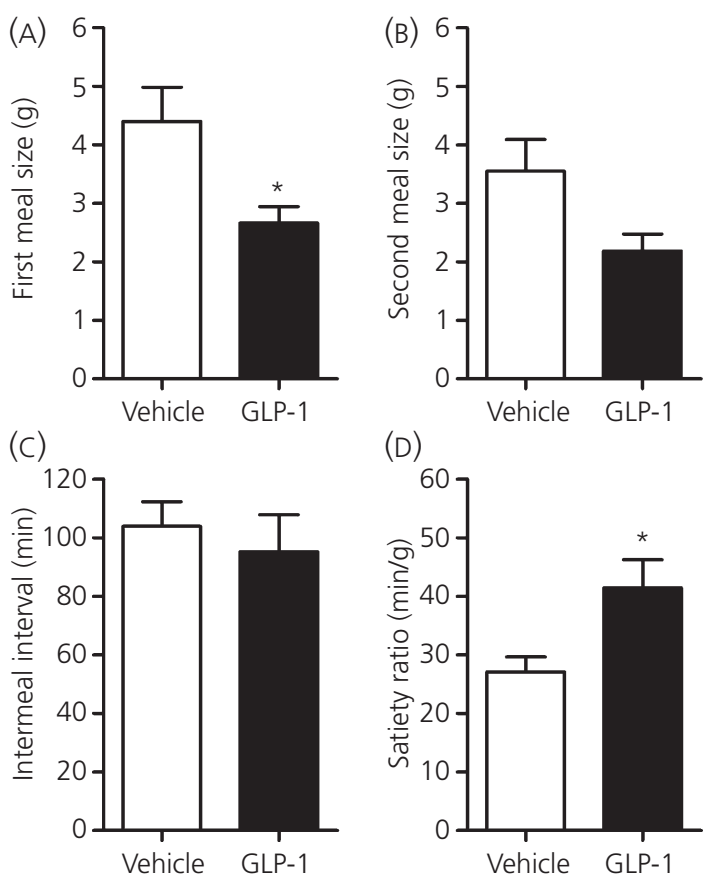

(D)

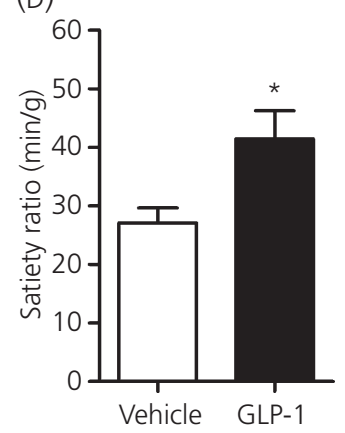

Fig. 1. Intrameal hepatic-portal vein infusions of $1 \mathrm{nmol} / \mathrm{kg}$ glucagon-like peptide-1 (GLP-1) reduced the size of the first meal compared to vehicle infusions (A), but not of the second meal (B). The intermeal interval between the first and the second meal was not affected by GLP-1 (c), but the first meal satiety ratio was increased (D). Values are the mean \pm SEM of ten rats. ${ }^{*} \mathrm{P}<0.05$.

HPV GLP-1 infusion also increased the number of c-Fos-positive cells in the CeA between 2.28 and $3.24 \mathrm{~mm}$ posterior to bregma, which reached statistical significance at 2.52 and $3.00 \mathrm{~mm}$ posterior to bregma (Fig. $3 A_{\text {; }}$ treatment effect: $F_{1,13}=8.78, P=0.006$, bregma level effect: $F_{5,44}=8.78, P<0.001, S E D=15$ cells/section). A significant interaction effect was found for the number of c-Fos-positive cells in the arcuate nucleus $\left(F_{8,81}=3.13, \quad P<0.001\right.$, $\mathrm{SED}=9$ cells/section). Post-hoc tests detected significant difference only at $3.16 \mathrm{~mm}$ posterior to bregma, which was probably the result of an unusually high number of c-Fos-positive cells in vehicle-treated rats because no such trend was observed in the adjacent sections (Fig. 3B). Finally, HPV GLP-1 infusion did not affect the number of c-Fos-positive cells in the PVN (Fig. 3c). More c-Fospositive cells were found at posterior levels of the PVN (bregma level effect: $F_{6,67}=13.30, \quad P<0.001, \quad S E D=12$ cells $/$ section), although there was no reliable treatment or interaction effect. c-Fos expression analyses were performed on fifteen rats that passed the catheter-patency tests. Representative examples of c-Fos staining in the CeA, arcuate nucleus and PVN are given in Fig. 3(D-I).

\section{Discussion}

The main novel finding of the present study is that the satiating action of intrameal HPV infusion of $1 \mathrm{nmol} / \mathrm{kg} \mathrm{GLP}-1$ in rats is associated with increased expression of c-Fos in the NTS, AP and CeA, but not in the arcuate nucleus or PVN. 
(A)

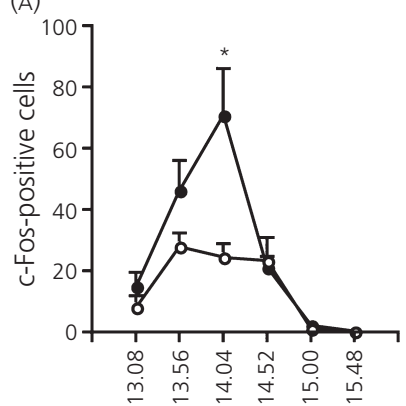

$\mathrm{mm}$ posterior to Bregma

(c)

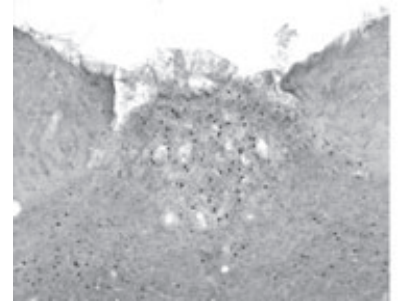

(B)

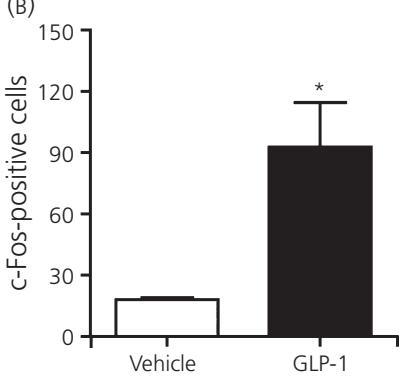

(D)

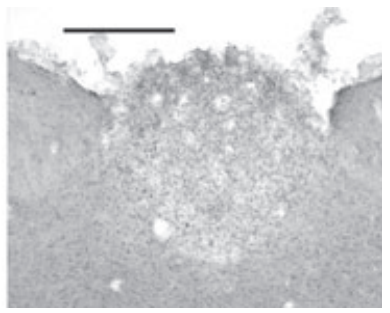

Fig. 2. Hepatic-portal vein infusions of $1 \mathrm{nmol} / \mathrm{kg}$ glucagon-like peptide- 1 (GLP-1) (filled symbols) increased the number of c-Fos-positive cells in the nucleus tractus solitarii (NTS) (A) and area postrema (AP) (B) compared to vehicle (open symbols) infusions. Values are the mean \pm SEM of 15 rats. ${ }^{*} P<0.05$. Representative examples of $c-F o s$ staining in the NTS and AP at $14.04 \mathrm{~mm}$ posterior to bregma in a GLP-1-treated (c) and vehicle-treated (D) rat are presented. Scale bar $=250 \mu \mathrm{m}$.

The specific neuronal activation pattern reported here has not been observed in previous studies of the effects of peripheral administration of GLP-1 or GLP-1R agonists. That is, we found more activation than some previous studies using comparably low doses of GLP-1 administered via different routes (22-24) and less activation than several studies using much larger doses $(25,26)$ or longlasting GLP-1 agonists $(22,27,28)$. For example, Yamamoto et al. (27) reported that femoral vein infusion of $0.24 \mathrm{nmol} / \mathrm{kg}(1 \mu \mathrm{g} / \mathrm{kg})$ of the potent GLP-1 agonist exendin (4-39) (Ex-4) increased c-Fos in the NTS, AP, PVN, arcuate nucleus and other areas. It is unlikely, however, that these effects of Ex-4 are directly comparable with what might be produced by HPV infusion of the GLP-1 dose that we used because GLP-1 is rapidly degraded by dipeptidyl peptidase IV, whereas Ex-4 is resistant to this enzyme and has several orders of magnitude greater biological activity than GLP-1 (29-31). For the same reason, the effects of long-acting GLP-1-albumin conjugates on c-Fos expression (22) are also of questionable relevance. There are two reports of the effects of i.p. injections of GLP-1 doses similar to ours in rats. Rowland et al. (23) reported that i.p. injection of $7.6 \mathrm{nmol} / \mathrm{kg} \mathrm{GLP}-1$ did not significantly increase c-Fos expression in the $A P, P V N$, arcuate nucleus or bed nucleus of the stria terminalis, and Neary et al. (24) failed to detect increases in c-Fos expression in the NTS, AP, PVN or arcuate nucleus after i.p. injection of $10 \mathrm{nmol} / \mathrm{kg}$ GLP-1. A higher i.p. dose, $100 \mathrm{nmol} / \mathrm{kg} \mathrm{GLP-1,} \mathrm{did} \mathrm{sig-}$ nificantly increase neuronal activation in the arcuate nucleus in rats (25) and in the NTS, arcuate nucleus and PVN in mice (26). Another study in mice (32), however, failed to detect increases in c-Fos expression in these areas or in the ventromedial hypothalamus,

supraoptic nucleus or CeA after i.p. injection of $900 \mathrm{nmol} / \mathrm{kg}$ GLP-1. It appears, therefore, that the effects of GLP-1 on c-Fos expression depend critically on the dose, route of administration, test conditions and, perhaps, species. In addition, as described above, i.p. and HPV GLP-1 infusions inhibit eating by recruiting different mechanisms (9), which may lead to differential central processing and, hence, differential neuronal activation.

The pattern of brain c-Fos expression after HPV GLP-1 that we observed resembles, in some respects, the effects of physiological satiation and, in other respects, the effects of more pharmacological treatments, including treatments that probably elicit some degree of visceral malaise, but is not identical to either. The pattern of increased c-Fos expression in the NTS, AP and CeA following HPV GLP-1 resembles the neuronal activation pattern after eating. Several studies in rats indicate that eating small amounts of food increases c-Fos expression in the NTS, CeA and PVN, but not in the AP (33-36). Eating larger amounts of food (e.g. in response to overnight food deprivation), however, recruits additional c-Fos expression in these areas and can lead to increased c-Fos expression in the AP $(37,38)$. Thus, the results obtained in the present study, with the exception of the lack of an increase in c-Fos expression in the PVN, are consistent with the hypotheses that HPV infusion of $1 \mathrm{nmol} / \mathrm{kg} \mathrm{GLP}-1$ has a similar effect in the brain as ingestion of a large meal and, by extension, that such meal-stimulated effects may be mediated by GLP-1 secretion. Very large meals, of course, may induce visceral malaise as well as satiation, as discussed by Rinaman et al. (37) and Verbalis et al. (39). Finally, the lack of effect of GLP-1 on c-Fos expression in the PVN may indicate that the eating-related feedback information encoded by GLP-1 under our conditions does not include information sufficient to activate the PVN, but further work would be required to confirm this.

Tests of other satiation signals provide further insight into the potential meaning of the pattern of c-Fos expression following HPV infusion of $1 \mathrm{nmol} / \mathrm{kg} \mathrm{GLP}-1$. For example, in a dose-response study of i.p. injected cholecystokinin (CCK-8), an intestinal peptide satiation signal, on c-Fos expression in the NTS (39), i.p. injection of $\leq 2 \mu \mathrm{g} / \mathrm{kg}$ CCK-8 failed to elicit c-Fos expression in the AP, whereas i.p. injection of $\geq 8 \mu \mathrm{g} / \mathrm{kg}$ CCK-8 clearly did. Importantly, doses of $\geq 8 \mu \mathrm{g} / \mathrm{kg}$ CCK-8 usually produce aversive effects (35). A study involving i.p. injection of $5 \mu \mathrm{g} / \mathrm{kg}$ amylin under a number of conditions (40) may be similarly interpreted: $5 \mu \mathrm{g} / \mathrm{kg}$ amylin failed to elicit c-Fos expression in the AP in ad lib fed rats, but did elicit c-Fos expression in $24 \mathrm{~h}$-fasted rats, which presumably is a more stressful situation. The association of increased AP c-Fos expression after larger versus smaller meals, larger versus smaller doses of CCK, and more versus less stressful situations are all consistent with the hypothesis that our treatment, HPV infusion of $1 \mathrm{nmol} / \mathrm{kg} \mathrm{GLP-1}$, may have produced some degree of visceral malaise or developing malaise. It is important to note, however, that because large, voluntary meals are one of the stimuli that produce a pattern of c-Fos expression including increased c-Fos expression in the AP, it is entirely likely that, under some conditions, GLP-1 and other eating-related feedback signals may produce both satiation and mild malaise, and that the two phenomena need not be mutually exclusive. GLP-1-expressing neurones in the caudal hind- 

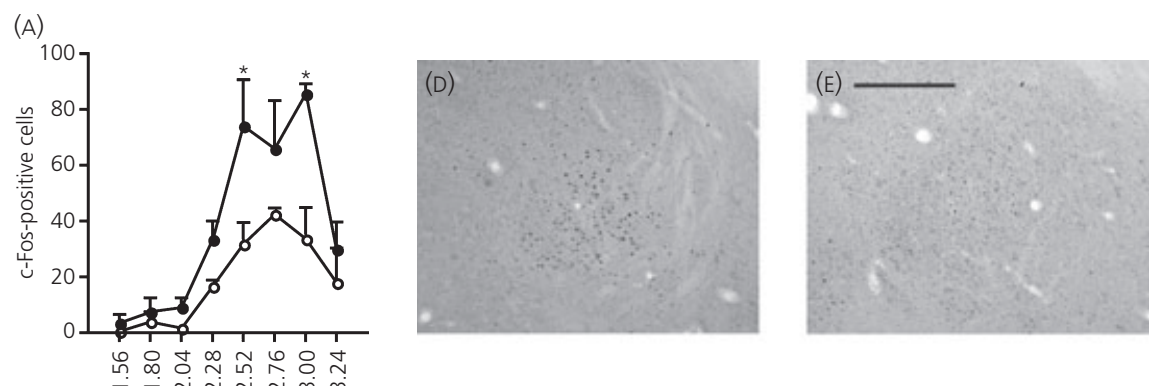

(B)
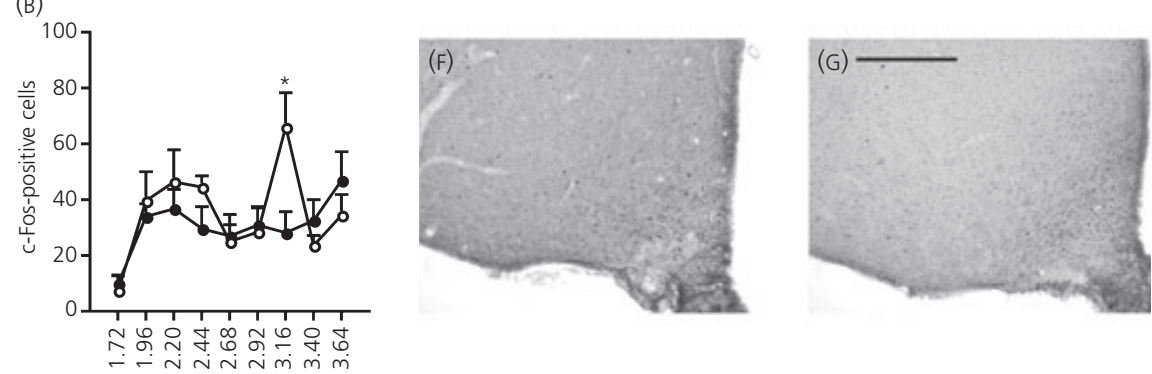

(c)
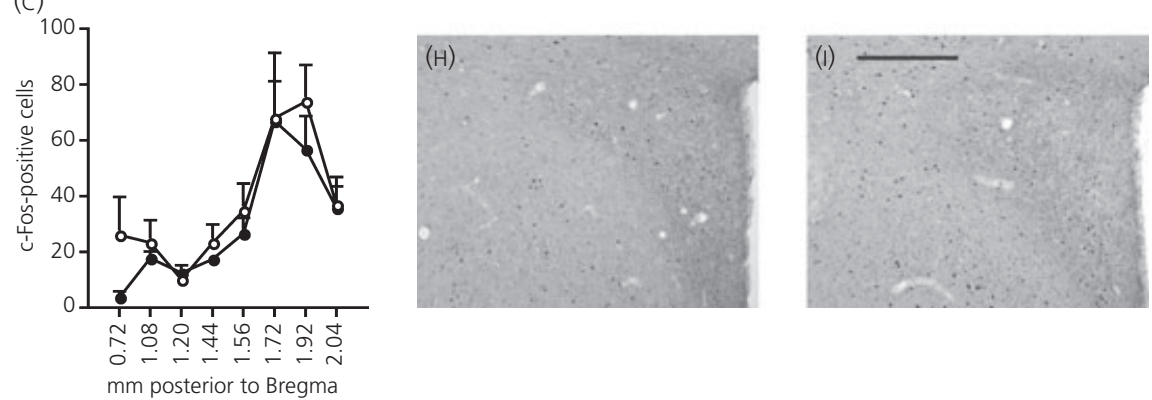

Fig. 3. Hepatic-portal vein infusions of $1 \mathrm{nmol} / \mathrm{kg}$ glucagon-like peptide-1 (GLP-1) (filled symbols) increased the number of c-Fos-positive cells in the central nucleus of the amygdala (CeA) (A), but not in the arcuate nucleus (B) and paraventricular nucleus (PVN) (C) compared to vehicle (open symbols) infusions. Values are the mean \pm SEM of 15 rats. ${ }^{*} P<0.05$. Representative examples of $C$-Fos staining in the CeA $(D, E)$, arcuate nucleus $(F, G)$, and PVN $(H, I)$ are presented for a GLP-1-treated and vehicle-treated rat. Scale bar $=250 \mu \mathrm{m}$.

brain, which also abundantly express GLP-1R, are interesting to consider in this context. Rinaman (41) reported that acute visceral malaise produced by treatments such as i.p. injection of $\mathrm{LiCl}$ elicited c-Fos expression in caudal hindbrain GLP-1 neurones, but that very large meals (approximately $30 \mathrm{ml}$ ) that produced robust c-Fos expression in the AP did not. On the other hand, it appears that gastric distension-induced activation of hindbrain GLP-1 neurones has a role in normal satiation $(42,43)$, likely including satiation after large meals. Finally, Gaykema et al. (44) reported a dissociation of the effects of satiation and malaise on activation of GLP-1 neurones: ingestion of a liquid meal induced c-Fos expression in NTS GLP-1 neurones, but not in the GLP-1 neurones in the ventrolateral medulla or adjacent reticular formation, whereas i.p. injection of $100 \mu \mathrm{g} / \mathrm{kg}$ LPS produced the opposite pattern. A doseresponse study of the effects of HPV GLP-1 on eating and c-Fos expression in hindbrain GLP-1 neurones would help to determine the role of endocrine GLP-1 in these pathways.

Although we have emphasised the eating-inhibitory actions of GLP-1 here, it is entirely possible that some or all of the c-Fos expression that we observed is related to other functions of GLP-1.
In particular, GLP-1R in the hepatic-portal area have been implicated in the increases in post-prandial insulin secretion and glucose clearance that are mediated by neural reflexes with vagal or spinal-visceral afferent arms $(9,45,46)$. Because both vagal and spinal-visceral afferents project to the NTS, it is possible that the increase in c-Fos expression we observed in the NTS after HPV infusions of GLP-1 was related to this function rather than to the control of eating.

Finally, it is worth noting that our eating data extend the data reported by Rüttimann et al. (9). Here, GLP-1 was HPV infused in rats re-fed at dark onset after $3 \mathrm{~h}$ of food deprivation and, under these conditions, GLP-1 reduced meal size and also increased the satiety ratio, whereas, previously (9), HPV GLP-1 infusions during truly spontaneous meals early in the dark phase reduced only meal size.

In conclusion, we have shown that GLP-1 infused via the HPV in a dose that reduced meal size increased c-Fos expression in the NTS, AP and CeA, suggesting a role for these brain areas in the eating-inhibitory action of GLP-1. Whether these effects on c-Fos expression reflect the activation of neural networks related to satiation or aversion, or both, the neurochemical phenotypes of the acti- 
vated cells, and their electrophysiological characteristics require further research.

\section{Acknowledgement}

This work was funded by the Danone Institute Germany.

Received: 7 November 2009,

revised 28 February 2010,

accepted 1 March 2010

\section{References}

1 Holst JJ. The physiology of glucagon-like peptide 1. Physiol Rev 2007; 87: 1409-1439.

2 Baggio LL, Drucker DJ. Biology of incretins: GLP-1 and GIP. Gastroenterology 2007; 132: 2131-2157.

3 Orskov C, Holst JJ, Nielsen OV. Effect of truncated glucagon-like peptide-1 [proglucagon-(78-107) amide] on endocrine secretion from pig pancreas, antrum, and nonantral stomach. Endocrinology 1988; 123: 2009-2013.

4 Holst JJ. Enteroglucagon. Annu Rev Physiol 1997; 59: 257-271.

5 Rinaman L. A functional role for central glucagon-like peptide-1 receptors in lithium chloride-induced anorexia. Am J Physiol Regul Integr Comp Physiol 1999; 277: R1537-R1540.

6 van Dijk G, Thiele TE. Glucagon-like peptide-1 (7-36) amide: a central regulator of satiety and interoceptive stress. Neuropeptides 1999; 33: 406-414.

7 Beglinger C, Degen L. Gastrointestinal satiety signals in humans - physiologic roles for GLP-1 and PYY? Physiol Behav 2006; 89: 460-464.

8 Williams DL. Minireview: finding the sweet spot: peripheral versus central glucagon-like peptide 1 action in feeding and glucose homeostasis. Endocrinology 2009; 150: 2997-3001.

9 Ruttimann EB, Arnold M, Hillebrand JJ, Geary N, Langhans W. Intrameal hepatic portal and intraperitoneal infusions of glucagon-like peptide-1 reduce spontaneous meal size in the rat via different mechanisms. Endocrinology 2009; 150: 1174-1181.

10 Thiele TE, van Dijk G, Campfield LA, Smith FJ, Burn P, Woods SC, Bernstein IL, Seeley RJ. Central infusion of GLP-1, but not leptin, produces conditioned taste aversions in rats. Am J Physiol Regul Integr Comp Physiol 1997; 272: R726-R730.

11 Williams DL, Baskin DG, Schwartz MW. Evidence that intestinal glucagon-like peptide-1 plays a physiological role in satiety. Endocrinology 2009; 150: 1680-1687.

12 Kinzig KP, D'Alessio DA, Seeley RJ. The diverse roles of specific GLP-1 receptors in the control of food intake and the response to visceral illness. J Neurosci 2002; 22: 10470-10476.

13 Seeley RJ, Blake K, Rushing PA, Benoit S, Eng J, Woods SC, D'Alessio D. The role of CNS glucagon-like peptide-1 (7-36) amide receptors in mediating the visceral illness effects of lithium chloride. J Neurosci 2000; 20: 1616-1621.

14 Thiele TE, Seeley RJ, D'Alessio D, Eng J, Bernstein IL, Woods SC, van Dijk G. Central infusion of glucagon-like peptide-1-(7-36) amide (GLP-1) receptor antagonist attenuates lithium chloride-induced c-Fos induction in rat brainstem. Brain Res 1998; 801: 164-170.

15 van Dijk G, Thiele TE, Seeley RJ, Woods SC, Bernstein IL. Glucagon-like peptide-1 and satiety. Nature 1997; 385: 214.

16 Verdich C, Flint A, Gutzwiller JP, Naslund E, Beglinger C, Hellstrom PM, Long SJ, Morgan LM, Holst JJ, Astrup A. A meta-analysis of the effect of glucagon-like peptide-1 (7-36) amide on ad libitum energy intake in humans. J Clin Endocrinology Metab 2001; 86: 4382-4389.
17 Kim DH, D'Alessio DA, Woods SC, Seeley RJ. The effects of GLP-1 infusion in the hepatic portal region on food intake. Regul Pept 2009; 155: 110-114.

18 Pacheco-Lopez G, Espinosa E, Zamorano-Rojas HM, Ramirez-Amaya $V_{\text {, }}$ Bermudez-Rattoni F. Peripheral protein immunization induces rapid activation of the CNS, as measured by c-Fos expression. I Neuroimmunol 2002; 131: 50-59.

19 Paxinos G, Watson C. The Rat Brain in Stereotaxic Coordinates, 2nd edn. San Diego, CA: Academic Press, 1986.

$20 \mathrm{Holm} \mathrm{S.} \mathrm{A} \mathrm{simple} \mathrm{sequentially} \mathrm{rejective} \mathrm{multiple} \mathrm{test} \mathrm{procedure.} \mathrm{Scand} \mathrm{J}$ Stat 1979; 6: 65-70.

21 Burke S. Missing Values, Outliers, Robust Statistics \& Non-Parameteric Methods. LG-GC Europe Online Supplement. http://www.lcgceurope.com/ Icgceurope/data/articlestandard/lcgceurope/502001/4509/article.pdf.

22 Yamamoto $H$, Kishi $T$, Lee $C E$, Choi BJ, Fang $H$, Hollenberg AN, Drucker DJ, Elmquist JK. Glucagon-like peptide-1-responsive catecholamine neurons in the area postrema link peripheral glucagon-like peptide-1 with central autonomic control sites. J Neurosci 2003; 23: 29392946.

23 Rowland NE, Crews EC, Gentry RM. Comparison of Fos induced in rat brain by GLP-1 and amylin. Regul Pept 1997; 71: 171-174.

24 Neary NM, Small CJ, Druce MR, Park AJ, Ellis SM, Semjonous NM, Dakin CL, Filipsson $K$, Wang F, Kent AS, Frost GS, Ghatei MA, Bloom SR. Peptide YY3-36 and glucagon-like peptide-17-36 inhibit food intake additively. Endocrinology 2005; 146: 5120-5127.

25 Abbott CR, Monteiro M, Small CJ, Sajedi A, Smith KL, Parkinson JR, Ghatei MA, Bloom SR. The inhibitory effects of peripheral administration of peptide $Y Y(3-36)$ and glucagon-like peptide-1 on food intake are attenuated by ablation of the vagal-brainstem-hypothalamic pathway. Brain Res 2005; 1044: 127-131.

26 Asarian L. Loss of cholecystokinin and glucagon-like peptide-1-induced satiation in mice lacking serotonin $2 \mathrm{C}$ receptors. Am J Physiol Regul Integr Comp Physiol 2009; 296: R51-R56.

27 Yamamoto H, Lee CE, Marcus JN, Williams TD, Overton JM, Lopez ME, Hollenberg AN, Baggio L, Saper CB, Drucker DJ, Elmquist JK. Glucagonlike peptide-1 receptor stimulation increases blood pressure and heart rate and activates autonomic regulatory neurons. J Clin Invest 2002; 110: 43-52.

28 Baggio LL, Huang Q, Brown TJ, Drucker DJ. A recombinant human glucagon-like peptide (GLP)-1-albumin protein (albugon) mimics peptidergic activation of GLP-1 receptor-dependent pathways coupled with satiety, gastrointestinal motility, and glucose homeostasis. Diabetes 2004; 53: 2492-2500.

29 Parkes DG, Pittner R, Jodka C, Smith P, Young A. Insulinotropic actions of exendin-4 and glucagon-like peptide- 1 in vivo and in vitro. Metabolism 2001; 50: 583-589.

$30 \mathrm{Kim}$ W, Egan JM. The role of incretins in glucose homeostasis and diabetes treatment. Pharmacol Rev 2008; 60: 470-512.

31 Young AA, Gedulin BR, Bhavsar S, Bodkin N, Jodka C, Hansen B, Denaro M. Glucose-lowering and insulin-sensitizing actions of exendin-4: studies in obese diabetic (ob/ob, db/db) mice, diabetic fatty Zucker rats, and diabetic rhesus monkeys (Macaca mulatta). Diabetes 1999; 48: 10261034.

32 Parkinson JR, Chaudhri OB, Kuo YT, Field BC, Herlihy AH, Dhillo WS, Ghatei MA, Bloom SR, Bell JD. Differential patterns of neuronal activation in the brainstem and hypothalamus following peripheral injection of GLP-1, oxyntomodulin and lithium chloride in mice detected by manganese-enhanced magnetic resonance imaging (MEMRI). Neuroimage 2009; 44: 1022-1031.

33 Eckel LA, Geary N. Estradiol treatment increases feeding-induced c-Fos expression in the brains of ovariectomized rats. Am J Physiol Regul Integr Comp Physiol 2001; 281: R738-R746. 
34 Fraser KA, Davison JS. Meal-induced c-fos expression in brain stem is not dependent on cholecystokinin release. Am J Physiol Regul Integr Comp Physiol 1993; 265: R235-R239.

35 Smith GP. Cholecystokinin: A Molecular Negative-Feedback Control of Eating. In: Pfaff DW, Arnold AP, Etgen AM, Fahrbach SE, Rubin RT, eds. Hormones, Brain and Behavior. San Diego, CA: Academic Press, 2009: 2527-2540.

36 Zittel T, Glatzle J, Kreis ME, Starlinger M, Eichner M, Raybould HE, Becker HD, Jehle EC. C-fos protein expression in the nucleus of the solitary tract correlates with cholecystokinin dose injected and food intake in rats. Brain Res 1999; 846: 1-11.

37 Rinaman L, Baker EA, Hoffman GE, Stricker EM, Verbalis JG. Medullary c-Fos activation in rats after ingestion of a satiating meal. Am J Physiol Regul Integr Comp Physiol 1998; 275: R262-R268.

38 Emond M, Schwartz GJ, Moran TH. Meal-related stimuli differentially induce c-Fos activation in the nucleus of the solitary tract. Am J Physiol Regul Integr Comp Physiol 2001; 280: R1315-R1321.

39 Verbalis JG, McCann MJ, McHale CM, Stricker EM. Oxytocin secretion in response to cholecystokinin and food: differentiation of nausea from satiety. Science 1986; 232: 1417-1419.

40 Michel S, Becskei C, Erguven E, Lutz TA, Riediger T. Diet-derived nutrients modulate the effects of amylin on c-Fos expression in the area postrema and on food intake. Neuroendocrinology 2007; 86: 124-135.
41 Rinaman L. Interoceptive stress activates glucagon-like peptide-1 neurons that project to the hypothalamus. Am J Physiol Regul Integr Comp Physiol 1999; 277: R582-R590.

42 Hayes MR, Bradley L, Grill HJ. Endogenous hindbrain glucagon-like peptide-1 receptor activation contributes to the control of food intake by mediating gastric satiation signaling. Endocrinology 2009; 150: $2654-$ 2659.

43 Vrang N, Phifer CB, Corkern MM, Berthoud HR. Gastric distension induces c-Fos in medullary GLP-1/2 containing neurons. Am J Physiol Regul Integr Comp Physiol 2003; 285: R470-R478.

44 Gaykema RP, Daniels TE, Shapiro NJ, Thacker GC, Park SM, Goehler LE. Immune challenge and satiety-related activation of both distinct and overlapping neuronal populations in the brainstem indicate parallel pathways for viscerosensory signaling. Brain Res 2009; 1294: 61-79.

45 Balkan B, Li X. Portal GLP-1 administration in rats augments the insulin response to glucose via neuronal mechanisms. Am J Physiol Regul Integr Comp Physiol 2000; 279: R1449-R1454.

46 Burcelin R, Da Costa A, Drucker D, Thorens B. Glucose competence of the hepatoportal vein sensor requires the presence of an activated glucagon-like peptide-1 receptor. Diabetes 2001; 50: 1720-1728. 


\section{Lebenslauf}

Name: $\quad$ Baumgartner, Isabelle

Geburtsdatum: 25.06.1983

Geburtsort:

Nationalität:

St.Gallen, Schweiz

Heimatort:

Schweiz

Sirnach TG

1990-1996

1996-1998

$1998-2002$

2002

2002-2007

2007

Primarschule Rossrüti SG, 1.-6. Klasse

Sekundarschule St. Katharina Wil SG, 1.-2. Sek

Kantonsschule am Burggraben St. Gallen

Matura, Kantonsschule am Burggraben St. Gallen

Studium der Veterinärmedizin an der Universität Zürich, Schweiz

2008-2009

Staatsexamen Veterinärmedizin an der Universität Zürich, Schweiz

Seit 2009

Doktorandin im Institut für Nutztierwissenschaften, Schwerzenbach, ETH Zürich

Assistentin in der Tierarztpraxis am Arenenberg AG, MannenbachSalenstein TG 